\title{
Molecular frequency and isolation of cyst-forming coccidia from free ranging chickens in Bahia State, Brazil
}

\author{
I.N. Gonçalves ${ }^{a}$, R.S. Uzêda ${ }^{a}$, G.A. Lacerda ${ }^{a}$, R.R.N. Moreira ${ }^{a}$, F.R. Araújo ${ }^{b}$, R.H.M. Oliveirab ${ }^{\text {, }}$ \\ L.G. Corbellini ${ }^{\mathrm{c}}$, L.F.P. Gondim ${ }^{\mathrm{a}, *}$ \\ a Universidade Federal da Bahia, Escola de Medicina Veterinária, Departamento de Patologia e Clínicas, Avenida Ademar de Barros, 500, Ondina, Salvador, \\ Bahia 40170-110, Brazil \\ b Empresa Brasileira de Pesquisa Agropecuária, Embrapa Gado de Corte, Campo Grande, Mato Grosso do Sul, Brazil \\ c Universidade Federal do Rio Grande do Sul, Faculdade de Veterinária, Departamento de Medicina Veterinária Preventiva, Porto Alegre, Rio Grande do Sul, \\ Brazil
}

\section{A R T I C L E I N F O}

\section{Article history:}

Received 17 March 2012

Received in revised form 10 May 2012

Accepted 11 May 2012

\section{Keywords:}

Toxoplasma gondii

Neospora caninum

Hammondia spp.

PCR

IFAT

Bioassay

\begin{abstract}
A B S T R A C T
The Toxoplasmatinae parasites Toxoplasma gondii, Neospora caninum and Hammondia spp. have carnivores as definitive hosts that shed the parasite oocysts in their feces. Birds that feed directly from the soil, such as chickens, are exposed to infection and may serve as indicators of the presence of the parasite in the environment and as a source of infection for other animals. The aims of this study were to determine the frequency of infection by these parasites in free ranging chickens, to test whether chickens are intermediate hosts of Hammondia spp., and to isolate N. caninum from chickens. One hundred chickens, which were raised in contact to cattle and dogs, were bought in five towns located in Bahia, Brazil. Blood and tissues (brain and heart) were used for serology, molecular tests and bioassay in mice for parasite isolation. $T$. gondii DNA was detected in 29 chickens, and $N$. caninum DNA was observed in six animals. Hammondia spp. DNA was not detected in tissues from any chicken. Tissues from eight $N$. caninum seropositive chickens were bioassayed in interferongamma gene knockout mice, but the mice did not become infected; T. gondii was isolated from six of 14 seropositive chickens after bioassay in outbreed Swiss mice. The authors concluded that: chickens seem to be better hosts for T. gondii when compared to N. caninum, based on the molecular and bioassay results; Hammondia spp. probably does not infect chickens or is rarely found in this animal species.
\end{abstract}

(c) 2012 Elsevier B.V. All rights reserved.

\section{Introduction}

Toxoplasma gondii, Neospora caninum and Hammondia spp. are cyst-forming coccidian parasites that belong to the subfamily Toxoplasmatinae (Frenkel and Smith, 2003). T. gondii is known to infect warm-blood animals, including birds, but most infected birds do not show sign of the disease (Dubey, 2002). Chickens are efficient intermediate

\footnotetext{
* Corresponding author. Tel.: +55 713283 6759; fax: +55 7132836730

E-mail address: pita@ufba.br (L.F.P. Gondim).
}

hosts of T. gondii and serve as good indicators of environmental contamination with oocysts (Dubey, 2010). T. gondii has been transmitted to mice and cats using tissues from naturally infected chickens (Dubey et al., 2005).

$N$. caninum infects several mammalian species and has been detected in chickens (Costa et al., 2008), sparrows (Passer domesticus) (Gondim et al., 2010), magpies (Pica pica) and buzzard (Buteo buteo) (Darwich et al., 2012), but the parasite has not been isolated from naturally infected birds so far. Experimental infections with $N$. caninum were performed in chickens and embryonated eggs; dogs that consumed $N$. caninum-infected embryonated eggs shed the 
parasite oocysts, suggesting that chickens may serve as intermediate hosts for the parasite (Costa et al., 2008; Gondim et al., 2010). Mansourian et al. (2009) have also demonstrated the susceptibility of embryonated eggs from broiler chickens to $N$. caninum infection. In both studies, embryo mortality and birth of sick chicks occurred after $N$. caninum infection. Recently, $N$. caninum antibodies were detected in $39.5 \%$ of 1324 chickens from several countries in America, showing a large exposure of chickens to the parasite in the studied regions (Martins et al., 2011). However, the role of chickens as intermediate hosts of $N$. caninum has not been demonstrated yet.

Hammondia hammondi and $H$. heydorni are closely related to T. gondii and $N$. caninum, respectively, and both have no clinical relevance in animals; however, infectious stages of Hammondia spp. are similar to T. gondii and $N$. caninum and should be differentiated from these parasites (Dubey et al., 2002b; Dubey and Sreekumar, 2003).

Chickens may be infected by $T$. gondii and $N$. caninum after ingestion of sporulated oocysts, mainly free ranging chickens which feed directly from the soil, being more exposed to oocysts (Dubey et al., 1993; Costa et al., 2008). Felines and canines are definitive hosts for T. gondii and N. caninum (Frenkel et al., 1970; McAllister et al., 1998), respectively, and may shed oocysts on the soil; these animals are also definitive hosts of Hammondia spp. (Frenkel and Dubey, 2000; Slapeta et al., 2002), so chickens are probably exposed to Hammondia spp. after ingestion of parasite oocysts from the soil. The aims of this study were to determine the molecular frequency of $N$. caninum, $T$. gondii and Hammondia spp. infection in free ranging chickens, to verify whether chickens serve as intermediate host of Hammondia spp., and to isolate $N$. caninum from naturally infected chickens.

\section{Materials and methods}

\subsection{Animals}

One hundred adult chickens were bought from small farmers in towns located $50-300 \mathrm{~km}$ far from Salvador, Bahia. This sample size is able to detect at least one infected chicken with $99 \%$ probability assuming a constant prevalence of $5 \%$ and infinite population. In all farms where the chickens were obtained, there were bovines and at least one dog. The animals were acquired in five towns: Serrinha (48 chickens), São Gonçalo (11), Irará (13), Itaparica Island (08), and Conceição de Feira (20). The chickens were transported to the Veterinary Hospital at the Universidade Federal da Bahia and were kept in individual metallic cages with water and commercial food until blood collection and euthanasia. After euthanasia the whole brain and heart tissues were collected for molecular analysis and mice bioassay.

Fourteen female Swiss mice and eight female interferon-gamma gene knockout (KO) mice, with ages between eight and 12 weeks, were obtained from Laboratório Central (LACEN/Bahia) and the Instituto Oswaldo Cruz (Fiocruz, Bahia), respectively. The Swiss mice were used in the bioassay for T. gondii and the KO mice in the bioassay for $N$. caninum.
All the animal procedures were performed in compliance with the Ethical Principles in Animal Research adopted by the Brazilian College of Animal Experimentation, and approved by the Institutional Bioethics Committee (Protocol: 001/2009).

\subsection{Nested PCR}

Heart and brain tissues from 100 chickens were used for DNA extraction. Half from each sample was individually homogenized with liquid nitrogen and the DNA was extracted using a commercial DNA extraction kit (Easy-DNA $^{\mathrm{TM}}$, Invitrogen, Carlsbad, CA, USA), according to the manufacturer's instructions. After the extraction, DNA samples were stored at $-20^{\circ} \mathrm{C}$ until the execution of the $\mathrm{PCR}$ reactions.

A nested PCR was performed to detect the internal transcribe spacer 1 (ITS1) of Toxoplasmatinae (T. gondii, $N$. caninum, and Hammondia spp.) rDNA, as previously described (Silva et al., 2009). Two pairs of primers complementary to portions of the ITS1 sequences conserved among Hammondia spp., $N$. caninum and T. gondii were employed. The first reaction used the external primer JS4 (5'-CGA AAT GGG AAG TTT TGT GAA C-3') (Slapeta et al., $2002)$, that anneals to the $3^{\prime}$ conserved region of the $18 \mathrm{~S}$ rRNA gene and CT2b (5'-TTG CGC GAG CCA AGA CAT C-3') (Monteiro et al., 2007), that anneals to the $5^{\prime}$ conserved region of the 5.8S rRNA gene. The second reaction used primers CT1 (5'-TGA ATC CCA AGC AAA ACA-3') and CT2 (5'-G CGC GAG CCA AGA CAT CCA T-3') (Sreekumar et al., 2003 ) that anneal to the $3^{\prime}$ region of the ITS1 and to the $5^{\prime}$ conserved region of the 5.8S rRNA gene, respectively.

Each amplification reaction was conducted in $25 \mu \mathrm{l}$ reaction mixtures containing $0.5 \mu$ l of each of the respective primer, $12.5 \mu \mathrm{l}$ of PCR commercial mix (Master Mix, Promega, Madison, WI, USA), $10.5 \mu$ l of ultra-pure water and $1.0 \mu \mathrm{l}$ of template DNA. Reactions were run in GeneAmp PCR System 9700 (Applied Biosystems, Foster City, CA, USA) thermal cycler.

The first PCR reaction (JS4/CT2b) was done under the following conditions: 40 cycles of $94^{\circ} \mathrm{C}$ for $1 \mathrm{~min}, 60^{\circ} \mathrm{C}$ for $1 \mathrm{~min}$ and $72^{\circ} \mathrm{C}$ for $1 \mathrm{~min}$. The second reaction (CT1/CT2) consisted of 40 cycles of $94^{\circ} \mathrm{C}$ for $1 \mathrm{~min}, 55^{\circ} \mathrm{C}$ for $1 \mathrm{~min}$ and $72^{\circ} \mathrm{C}$ for $1 \mathrm{~min}$; both preceded by an initial denaturation step of $94^{\circ} \mathrm{C}$ for $5 \mathrm{~min}$ and followed by a final extension at $72{ }^{\circ} \mathrm{C}$ for $7 \mathrm{~min}$. The expected size of the amplicon was about 500 bp for the first reaction and $400 \mathrm{bp}$ for the second one. Positive control DNA was from $H$. heydorni oocysts from a naturally infected dog (Monteiro et al., 2007) and negative control consisted of ultra-pure water.

The PCR products were analyzed by electrophoresis in a $2 \%$ agarose gel stained with "Blue Green Loading Dye I" (LGC, Biotecnologia, Cotia, SP, Brazil) and visualized under ultraviolet light. A 100 bp DNA ladder (Invitrogen, Carlsbad, CA, USA) was used as a marker. When amplicons were visualized, reactions were repeated using the original genomic DNA and each positive sample was again subjected to electrophoresis in 1\% agarose gel for amplicon isolation. The amplicons were excised with a fine scalpel blade and extracted from the gel using the Wizard SV Gel 
and PCR Clean-Up System kit (Promega, Madison, WI, USA) according to the manufacturer's instructions.

\subsection{Species-specific PCR for T. gondii and N. caninum}

To confirm the identity of the tachyzoites isolated in cell culture, conventional species-specific PCRs were conducted for T. gondii and $N$. caninum using the primers TgB1.1/TgB1.4 (Burg et al., 1989) and Np21/Np6 (Yamage et al., 1996), respectively, according to protocols described by the mentioned authors.

\subsection{Sequencing procedures}

The PCR products were directly sequenced in the forward and reverse directions using the primers CT1/CT2 and the Big Dye Terminator 3.1 (Applied Biosystems, Foster City, CA, USA) according to the manufacturer's instructions. The thermocycling conditions consisted of $96^{\circ} \mathrm{C}$ for $1 \mathrm{~min}$, 25 cycles of $96^{\circ} \mathrm{C}$ for $10 \mathrm{~s}, 50^{\circ} \mathrm{C}$ for $5 \mathrm{~s}$, and $60^{\circ} \mathrm{C}$ for $4 \mathrm{~min}$. These steps were all performed in slow ramp $\left(1^{\circ} \mathrm{C} / \mathrm{s}\right)$. The purification was conducted by ethanol/EDTA method. The basecalling was done using the software Sequence Analysis (Applied Biosystems, Foster City, CA, USA) and the quality of the sequences was evaluated using the software Sequence Scanner (Applied Biosystems, Foster City, CA, USA). The sequencing results were edited using the programs Pregap 4, version 1.5, and Gap, version 4.10 (Staden Package, http://staden.sourceforge.net/). The sequences were submitted to homology search by BLASTN at the NCBI server (http://www.ncbi.nlm.nih.gov/BLAST/).

\subsection{Immunofluorescent antibody tests}

Chicken and mouse sera were tested for $N$. caninum and for $T$. gondii using immunofluorescent antibody tests (IFAT) according to methods previously described (Costa et al., 2008). IFATs for $N$. caninum and $T$. gondii were performed using tachyzoites of the strains NC-Bahia (Gondim et al., 2001) and RH as antigens, respectively. Commercial fluorescein-labeled anti-chicken IgG (Zymed, Invitrogen, Camarillo, CA, USA) or anti-mouse IgG (Sigma, St. Louis, MO, USA) were used as the secondary antibodies. The samples were screened for $T$. gondii at a 1:50 dilution (mouse sera) and at 1:16 dilution (chicken sera). The sera for $N$. caninum were screened at 1:50 for both chicken and mouse (Costa et al., 2008). A reaction was considered positive if fluorescence occurred around the complete periphery of tachyzoites. Positive sera were diluted 2-fold until the end point. Negative and positive controls sera were included on each slide.

\subsection{Bioassay and in vitro isolation}

Brain and heart tissues ( $1 / 4$ of each organ) from chickens that tested positive for $T$. gondii or $N$. caninum antibodies were collected and kept for 1-48 h in PBS with $2 \%$ of antibiotic/antimycotic solution (Invitrogen, Auckland, New Zealand) for parasite isolation attempts. The tissues were processed as previously described with slight modifications (Gondim et al., 2001). Briefly, the tissues were macerated in an equal volume of PBS with antibiotic/antimycotic. The suspension was filtered in sterile gauze, centrifuged at $1000 \times g$ for $10 \mathrm{~min}$, and the sediment was treated with $0.25 \%$ trypsin solution for $30 \mathrm{~min}$ at $37^{\circ} \mathrm{C}$. After incubation the mixture was washed with PBS by centrifugation three times at $1000 \times g$ for $5 \mathrm{~min}$. The sediment was separated and used for animal inoculations.

The KO mice and Swiss mice were employed for $N$. caninum and $T$. gondii isolation, respectively. Each mouse was inoculated intraperitoneally with $0.5 \mathrm{ml}$ of processed brain and heart from each seropositive chicken. Animals which presented any clinical sign were euthanized in a chamber with enflurane (Farmasa, SP, Brazil). The remaining mice were maintained until 50 days after inoculation, and then euthanized as described above. Blood samples from mice were collected after euthanasia for serology. Only the seropositive mice were used for cell culture isolation attempts, according to previously described methods (Gondim et al., 2001). Tachyzoites observed in cell culture were submitted to species-specific PCR for N. caninum and T. gondii (described above).

\subsection{Statistical analysis}

Data from cross tabulation between serological tests of $N$. caninum and T. gondii, and nested PCR performed in the heart and brain, were used to test the correlation by Kappa statistics. $P$ values $\leq 0.05$ were considered as statistically significant.

\section{Results}

Nested PCR-positive reactions for the subfamily Toxoplasmatinae were observed in 42 of 100 tested chickens (42\%). DNA fragments detected in the tested tissues had approximately $400 \mathrm{bp}$. DNA from the studied species were identified in 35 of the 42 PCR-positive chickens. The poor amount or quality of DNA obtained from seven chickens impaired the nucleotide sequencing of these bird samples.

After sequencing of the PCR products from the second amplification, T. gondii DNA was observed in 29 chickens (GenBank ${ }^{\mathrm{TM}}$ accession nos. JF810931-JF810959), and $N$. caninum DNA was detected in six birds (GenBank ${ }^{\mathrm{TM}}$ accession nos. JF810960-JF810965). The sequences identified as T. gondii matched $99-100 \%$ with each other and with other sequences deposited in GenBank ${ }^{\mathrm{TM}}$ (accession nos. EU025025, AY582110, AF252408, and U16161), except the sequence from one chicken (accession no. JF810938), which shared $92 \%$ of similarity with the sequences mentioned above. The sequences identified as $N$. caninum matched $99-100 \%$ with each other and with other sequences deposited in GenBank ${ }^{\mathrm{TM}}$ (accession nos. GQ899204, GU194959, AF432123, and AF029702). No chickens presented simultaneous infection with both parasites.

Positive PCR reactions for Toxoplasmatinae DNA were observed in 30 brains and in 25 hearts; $13 \%$ of the samples had simultaneous infections in the brain and heart for a unique parasite species. There was a significant agreement between the PCR results in both organs (Kappa $=0.27$; $P=0.006)$. T. gondii DNA was detected in 22 brains and in 15 
Table 1

Nested PCR for Toxoplasmatinae, tissue containing parasite DNA, and species identification by nucleotide sequencing in 100 free ranging chickens from Bahia, Brazil.

\begin{tabular}{lcccc}
\hline Parasite DNA & Brain & Heart & In both brain and heart \\
\hline Toxoplasmatinae & 30 & 25 & 13 \\
Toxoplasma gondii & 22 & 15 & 8 & 42 \\
Neospora caninum & 3 & 3 & 0 & 29 \\
\hline
\end{tabular}

hearts; eight chickens presented the parasite DNA in both brain and heart. $N$. caninum DNA was observed in three brains and in three hearts (Table 1). Hammondia spp. DNA was not detected in any chicken.

Antibodies to T. gondii were found in $25 \%$ of the serum samples, while antibodies to $N$. caninum were detected in $17 \%$. A total of $9 \%$ of the chickens were seropositive for both parasites (Table 2). A significant agreement was observed in the serology for both $T$. gondii and $N$. caninum (Kappa $=0.28$; $P=0.03$ ). Twenty-two out of the 42 PCR-positive chickens for Toxoplasmatinae DNA were also positive by IFAT for at least one of the tested parasites (T. gondii and $N$. caninum) (Kappa $=0.34 ; P<0.001) . T$. gondii DNA was detected in 15 seropositive chickens and in 14 seronegative chickens. The six PCR-positive chickens for $N$. caninum were seronegative for the parasite by IFAT. The antibody titers ranged from 16 to 4096 for T. gondii, and from 50 to 400 for N. caninum.

Tissues from 14 of $25 \mathrm{~T}$. gondii-seropositive chickens were processed for bioassay in mice. Eight mice seroconverted and were euthanized for in vitro isolation attempts. Six isolates were obtained from the eight seropositive mice. Tachyzoites were grown in cell culture and confirmed to be $T$. gondii by a species-specific PCR. The isolates were obtained from chickens which had antibody titers for $T$. gondii between 64 and 4096 .

Isolation attempts of $N$. caninum using the KO mice inoculated with tissues from eight $N$. caninum-seropositive chickens were negative. No seroconversion occurred in the eight inoculated mice. The chickens which were seropositive simultaneously for both parasites (nine birds) were not used in the bioassay for $N$. caninum.

\section{Discussion}

In the present study, Toxoplasmatinae DNA was investigated in tissues from 100 chickens that were raised close to cattle and dogs; since dogs and cattle are important hosts for $N$. caninum and $H$. heydorni (McAllister et al., 1998; Soares et al., 2009), the authors intended to select chickens exposed to both parasites and to reach two of the three proposed objectives in the study, which were to in vitro isolate $N$. caninum from chickens and to detect $H$. heydorni DNA in chicken tissues.

A nested PCR was used in this work because it successfully detected DNA of Toxoplasmatinae parasites ( $N$. caninum, T. gondii and Hammondia heydorni) in previous studies (Silva et al., 2009; Gondim et al., 2010; Santos et al., 2010). Brain and heart tissues were used in this study because Silva et al. (2009) were able to detect $N$. caninum, $T$. gondii and $H$. heydorni in Bahia using brain and heart tissues from goats. Toxoplasmatinae DNA was observed in $42 \%$ of the chickens. After sequencing the amplicons, we observed that the number of chickens infected with $T$. gondii was higher than the number infected with $N$. caninum. The higher proportion of $T$. gondii-infected chickens may be due to the fact that the amount of $T$. gondii oocysts shed in cat feces is significantly greater than the amount of $N$. caninum oocysts shed by dogs. One single cat may shed over 20 million oocysts (Dubey, 1995), while the maximum numbers of oocysts shed by dogs is usually inferior to one million (Schares et al., 2001; Gondim et al., 2002). In addition, it is possible that chickens are less susceptible to $N$. caninum infection when compared to T. gondii.

All chickens were tested for T. gondii and N. caninum antibodies by IFAT. Antibodies were not tested to $H$. heydorni or $H$. hammondi because there is no serology available for these parasites. T. gondii DNA was detected from seropositive and seronegative chickens. Some chickens may harbor the parasite in their tissues without presenting detectable specific antibodies or with low antibody titers, as previously observed (Dubey et al., 2002a), what may explain the detection of the parasite DNA in seronegative birds. Nine chickens that were seropositive for $T$. gondii or $N$. caninum did not show positive reactions in the nested PCR for Toxoplasmatinae DNA; however, the specific antibody response might have been induced by parasites present in other tissues not included in the study.

Table 2

Immunofluorescent antibody tests (IFAT) for IgG to Toxoplasma gondii and Neospora caninum versus parasite DNA in tissues (brain and heart) from free ranging chickens in Bahia, Brazil.

\begin{tabular}{|c|c|c|c|c|c|c|c|}
\hline \multirow[t]{2}{*}{ Towns } & \multirow[t]{2}{*}{ Number of chickens } & \multicolumn{3}{|c|}{ Positive IFAT } & \multicolumn{3}{|l|}{ DNA } \\
\hline & & T. gondii & N. caninum & T. gondii and N. caninum & Toxoplasmatinae & T. gondii & N. caninum \\
\hline Conceição de Feira & 20 & 0 & 1 & 0 & 2 & 1 & 0 \\
\hline Ilha de Itaparica & 8 & 2 & 6 & 2 & 1 & 1 & 0 \\
\hline Irará & 13 & 4 & 2 & 2 & 10 & 7 & 2 \\
\hline São Gonçalo & 11 & 5 & 5 & 4 & 8 & 7 & 0 \\
\hline Serrinha & 48 & 14 & 3 & 1 & 21 & 13 & 4 \\
\hline Total & 100 & 25 & 17 & 9 & $42^{\mathrm{a}}$ & 29 & 6 \\
\hline
\end{tabular}

a Parasite identification could not be determined in seven of the 42 PCR-positive chickens for Toxoplasmatinae DNA. 
Hammondia spp. DNA was not detected in tissues from any chicken. Hammondia spp. oocysts are shed in feces of cats, dogs and foxes (Dubey and Sreekumar, 2003; Schares et al., 2005; Soares et al., 2009), so chickens are probably exposed to ingestion of these parasites from the ground. A new Hammondia sp. of foxes has recently been described and named as Hammondia triffittae (Gjerde and Dahlgren, 2011), however their definitive hosts, the red fox (Vulpes vulpes) and the arctic fox (Vulpes lagopus), are not natural habitants of South America. In a previous study also conducted in Bahia state, goats were shown to be infected with H. heydorni (Silva et al., 2009), what confirms the presence of the parasite in the studied region. Both $N$. caninum and $H$. heydorni have dogs as definitive hosts; the detection of $N$. caninum DNA in chicken tissues is indicative of the exposure of chickens to dog feces. The lack of $H$. heydorni DNA detection in chicken tissues is suggestive that chickens are not intermediate hosts for this parasite or $H$. heydorni infection in chickens is rare (at least less than 5\% prevalence). More studies need to be conducted to prove whether Hammondia spp. infection occurs in chickens.

Chickens are known to be efficient hosts of $T$. gondii and are good markers of environmental contamination with oocysts; several studies have reported $T$. gondii isolation from chicken tissues in Brazil using bioassay in mice (da Silva et al., 2003; de Oliveira et al., 2009; Dubey et al., 2010). N. caninum is known to infect chickens (Costa et al., 2008), but no cysts of the parasite were detected in naturally infected chickens neither viable isolates have been obtained from this animal species.

The in vitro isolation of $T$. gondii in this study was performed using Swiss outbreed mice, which are known to be susceptible to infection by the parasite (Dubey, 1967; Dubey et al., 1995). T. gondii was isolated from six of 14 mice which had been inoculated with tissues from seropositive chickens; mouse tissues were used for isolation of the parasite in cell culture. The attempts to isolate $N$. caninum from seropositive chickens were performed by inoculation of chicken tissues into interferon-gamma KO mice, because heterozygous immunocompetent mice are resistant to $\mathrm{N}$. caninum infection (Lindsay and Dubey, 1989). Tissues from eight $N$. caninum-seropositive chickens were processed and inoculated into eight interferon-gamma $\mathrm{KO}$ mice, but no mouse presented clinical signs or seroconverted to $N$. caninum. Isolation of $N$. caninum from mammalian tissues has been successfully conducted using interferon-gamma KO mice (Dubey et al., 1998; Basso et al., 2001; Canada et al., 2004). Due to ethical concerns, only one mouse was used for each seropositive chicken in the attempts to isolate $T$. gondii or $N$. caninum. The authors speculate that a higher number of parasite isolates would be obtained if more than one mouse per infected chicken were used in the bioassay.

The lack of isolation of $N$. caninum from eight seropositive chickens using a well-established animal model is suggestive that infected chickens, in contrast to $T$. gondii, have parasite in very low numbers with irregular distribution in tissues or do not possess mature parasite stages in their tissues capable to infect mice and possibly in other animals. The authors suspect that the temperature range required by $N$. caninum to develop into a mature tissue cyst is different from that required by $T$. gondii. The body temperature of chickens is around $42{ }^{\circ} \mathrm{C}$ (Yalcin et al., 2008), what is quite higher than the body temperature of some efficient hosts of the parasite, such as cattle and dogs (Angle and Gillette, 2011; Wenz et al., 2011). In a previous study, dogs were induced to shed oocysts after ingestion of chicken embryonated eggs infected with $N$. caninum (Furuta et al., 2007). However, the temperature used to incubate chicken eggs is between $37.5^{\circ} \mathrm{C}$ (Shim and Pesti, 2011), what is lower than the body temperature of adult chickens that were used in the current work. Infective stages of $T$. gondii may develop in a wider temperature range, as demonstrated by bioassays using bird tissues (Dubey, 2002).

The authors concluded that chickens seem to be better hosts for $T$. gondii when compared to $N$. caninum, based on the molecular detection of the parasites and on the results of the bioassays in mice. So far, neither tissue cysts of $N$. caninum nor viable isolates of the parasite have been reported using chicken tissues. Recently, tissue cysts positively immunostained to $N$. caninum were reported in two wild birds (Mineo et al., 2011); however, the authors could not confirm the identity of the cysts because no DNA was available.

Due to the global distribution of chickens and their use for human and animal nutrition, more studies are necessary to confirm whether $N$. caninum can be transmitted to animals through the consumption of infected tissues from chickens. It is also important to conduct more studies about Hammondia spp. infection in birds and to test their potential role as intermediate hosts of these parasites.

\section{Acknowledgements}

To Dr. Ricardo Portela (UFBA) for technical help. This work was supported by Fundação de Amparo a Pesquisa do Estado da Bahia (FAPESB). Ilka. N. Gonçalves was recipient of a fellowship from Conselho Nacional de Desenvolvimento Científico e Tecnológico (CNPq). Luís F.P. Gondim was recipient of a productivity fellowship from CNPq.

\section{References}

Angle, T.C., Gillette, R.L., 2011. Telemetric measurement of body core temperature in exercising unconditioned Labrador retrievers. Can. J. Vet. Res. 75, 157-159.

Basso, W., Venturini, L., Venturini, M.C., Hill, D.E., Kwok, O.C., Shen, S.K. Dubey, J.P., 2001. First isolation of Neospora caninum from the feces of a naturally infected dog. J. Parasitol. 87, 612-618.

Burg, J.L., Grover, C.M., Pouletty, P., Boothroyd, J.C., 1989. Direct and sensitive detection of a pathogenic protozoan, Toxoplasma gondii, by polymerase chain reaction. J. Clin. Microbiol. 27, 1787-1792.

Canada, N., Meireles, C.S., Mezo, M., Gonzalez-Warleta, M., Correia da Costa, J.M., Sreekumar, C., Hill, D.E., Miska, K.B., Dubey, J.P., 2004. First isolation of Neospora caninum from an aborted bovine fetus in Spain. J. Parasitol. 90, 863-864.

Costa, K.S., Santos, S.L., Uzeda, R.S., Pinheiro, A.M., Almeida, M.A., Araujo, F.R., McAllister, M.M., Gondim, L.F., 2008. Chickens (Gallus domesticus) are natural intermediate hosts of Neospora caninum. Int. J. Parasitol. 38, 157-159.

da Silva, D.S., Bahia-Oliveira, L.M., Shen, S.K., Kwok, O.C., Lehman, T., Dubey, J.P., 2003. Prevalence of Toxoplasma gondii in chickens from an area in southern Brazil highly endemic to humans. J. Parasitol. 89, 394-396.

Darwich, L., Cabezon, O., Echeverria, I., Pabon, M., Marco, I., Molina-Lopez, R., Alarcia-Alejos, O., Lopez-Gatius, F., Lavin, S., Almeria, S., 2012 
Presence of Toxoplasma gondii and Neospora caninum DNA in the brain of wild birds. Vet. Parasitol. 183, 377-381.

de Oliveira, L.N., Costa Junior, L.M., de Melo, C.F., Ramos Silva, J.C., Bevilaqua, C.M., Azevedo, S.S., Muradian, V., Araujo, D.A., Dubey, J.P., Gennari, S.M., 2009. Toxoplasma gondii isolates from free-range chickens from the northeast region of Brazil. J. Parasitol. 95, 235-237.

Dubey, J.P., 1967. Distribution of Toxoplasma gondii in the tissues of infected cats. I. Isolation in mice. Trop. Geogr. Med. 19, 199-205.

Dubey, J.P., 1995. Duration of immunity to shedding of Toxoplasma gondii oocysts by cats. J. Parasitol. 81, 410-415.

Dubey, J.P., 2002. A review of toxoplasmosis in wild birds. Vet. Parasitol. $106,121-153$.

Dubey, J.P., 2010. Toxoplasma gondii infections in chickens (Gallus domesticus): prevalence, clinical disease, diagnosis and public health significance. Zoonoses Public Health 57, 60-73.

Dubey, J.P., Dorough, K.R., Jenkins, M.C., Liddell, S., Speer, C.A., Kwok, O.C., Shen, S.K., 1998. Canine neosporosis: clinical signs, diagnosis, treatment and isolation of Neospora caninum in mice and cell culture. Int. J. Parasitol. 28, 1293-1304.

Dubey, J.P., Edelhofer, R., Marcet, P., Vianna, M.C., Kwok, O.C., Lehmann, T., 2005. Genetic and biologic characteristics of Toxoplasma gondii infections in free-range chickens from Austria. Vet. Parasitol. 133, 299-306.

Dubey, J.P., Graham, D.H., Blackston, C.R., Lehmann, T., Gennari, S.M., Ragozo, A.M., Nishi, S.M., Shen, S.K., Kwok, O.C., Hill, D.E., Thulliez, P., 2002a. Biological and genetic characterisation of Toxoplasma gondii isolates from chickens (Gallus domesticus) from Sao Paulo, Brazil: unexpected findings. Int. J. Parasitol. 32, 99-105.

Dubey, J.P., Hill, D.E., Lindsay, D.S., Jenkins, M.C., Uggla, A., Speer, C.A., 2002b. Neospora caninum and Hammondia heydorni are separate species/organisms. Trends Parasitol. 18, 66-69.

Dubey, J.P., Rajendran, C., Costa, D.G., Ferreira, L.R., Kwok, O.C., Qu, D., Su, C., Marvulo, M.F., Alves, L.C., Mota, R.A., Silva, J.C., 2010. New Toxoplasma gondii genotypes isolated from free-range chickens from the Fernando de Noronha, Brazil: unexpected findings. J. Parasitol. 96, 709-712.

Dubey, J.P., Ruff, M.D., Camargo, M.E., Shen, S.K., Wilkins, G.L., Kwok, O.C., Thulliez, P., 1993. Serologic and parasitologic responses of domestic chickens after oral inoculation with Toxoplasma gondii oocysts. Am. J. Vet. Res. 54, 1668-1672.

Dubey, J.P., Sreekumar, C., 2003. Redescription of Hammondia hammondi and its differentiation from Toxoplasma gondii. Int. J. Parasitol. 33, 1437-1453.

Dubey, J.P., Thulliez, P., Powell, E.C., 1995. Toxoplasma gondii in Iowa sows: comparison of antibody titers to isolation of $T$. gondii by bioassays in mice and cats. J. Parasitol. 81, 48-53.

Frenkel, J.K., Dubey, J.P., 2000. The taxonomic importance of obligate heteroxeny: distinction of Hammondia hammondi from Toxoplasma gondii-another opinion. Parasitol. Res. 86, 783-786.

Frenkel, J.K., Dubey, J.P., Miller, N.L., 1970. Toxoplasma gondii in cats: fecal stages identified as coccidian oocysts. Science 167, 893-896.

Frenkel, J.K., Smith, D.D., 2003. Determination of the genera of cystforming coccidia. Parasitol. Res. 91, 384-389.

Furuta, P.I., Mineo, T.W., Carrasco, A.O., Godoy, G.S., Pinto, A.A., Machado, R.Z., 2007. Neospora caninum infection in birds: experimental infections in chicken and embryonated eggs. Parasitology 134, 1931-1939.

Gjerde, B., Dahlgren, S.S., 2011. Hammondia triffittae n. comb. of foxes (Vulpes spp.): biological and molecular characteristics and differentiation from Hammondia heydorni of dogs. Parasitology 138, 303-321.

Gondim, L.F., Pinheiro, A.M., Santos, P.O., Jesus, E.E., Ribeiro, M.B., Fernandes, H.S., Almeida, M.A., Freire, S.M., Meyer, R., McAllister, M.M., 2001. Isolation of Neospora caninum from the brain of a naturally infected $\mathrm{dog}$, and production of encysted bradyzoites in gerbils. Vet. Parasitol. $101,1-7$.

Gondim, L.F.P., Gao, L., McAllister, M.M., 2002. Improved production of Neospora caninum oocysts, cyclical oral transmission between dogs and cattle, and in vitro isolation from oocysts. J. Parasitol. 88, 1159-1163.
Gondim, L.S., Abe-Sandes, K., Uzeda, R.S., Silva, M.S., Santos, S.L., Mota, R.A., Vilela, S.M., Gondim, L.F., 2010. Toxoplasma gondii and Neospora caninum in sparrows (Passer domesticus) in the Northeast of Brazil. Vet. Parasitol. 168, 121-124.

Lindsay, D.S., Dubey, J.P., 1989. Neospora caninum (Protozoa: apicomplexa) infections in mice. J. Parasitol. 75, 772-779.

Mansourian, M., Khodakaram-Tafti, A., Namavari, M., 2009. Histopathological and clinical investigations in Neospora caninum experimentally infected broiler chicken embryonated eggs. Vet. Parasitol. 166, 185-190.

Martins, J., Kwok, O.C., Dubey, J.P., 2011. Seroprevalence of Neospora caninum in free-range chickens (Gallus domesticus) from the Americas. Vet. Parasitol. 182, 349-351.

McAllister, M.M., Dubey, J.P., Lindsay, D.S., Jolley, W.R., Wills, R.A., McGuire, A.M., 1998. Dogs are definitive hosts of Neospora caninum. Int. J. Parasitol. 28, 1473-1478.

Mineo, T.W., Carrasco, A.O., Raso, T.F., Werther, K., Pinto, A.A., Machado, R.Z., 2011. Survey for natural Neospora caninum infection in wild and captive birds. Vet. Parasitol. 182, 352-355.

Monteiro, R.M., Richtzenhain, L.J., Pena, H.F., Souza, S.L., Funada, M.R., Gennari, S.M., Dubey, J.P., Sreekumar, C., Keid, L.B., Soares, R.M., 2007. Molecular phylogenetic analysis in Hammondia-like organisms based on partial Hsp70 coding sequences. Parasitology 134, 1195-1203.

Santos, S.L., de Souza Costa, K., Gondim, L.Q., da Silva, M.S., Uzeda, R.S. Abe-Sandes, K., Gondim, L.F., 2010. Investigation of Neospora caninum, Hammondia sp., and Toxoplasma gondii in tissues from slaughtered beef cattle in Bahia, Brazil. Parasitol. Res. 106, 457-461.

Schares, G., Heydorn, A.O., Cuppers, A., Conraths, F.J., Mehlhorn, H., 2001. Hammondia heydorni-like oocysts shed by a naturally infected dog and Neospora caninum NC-1 cannot be distinguished. Parasitol. Res. 87, 808-816.

Schares, G., Pantchev, N., Barutzki, D., Heydorn, A.O., Bauer, C., Conraths, F.J., 2005. Oocysts of Neospora caninum, Hammondia heydorni, Toxoplasma gondii and Hammondia hammondi in faeces collected from dogs in Germany. Int. J. Parasitol. 35, 1525-1537.

Shim, M.Y., Pesti, G.M., 2011. Effects of incubation temperature on the bone development of broilers. Poult. Sci. 90, 1867-1877.

Silva, M.S., Uzeda, R.S., Costa, K.S., Santos, S.L., Macedo, A.C., Abe-Sandes, K., Gondim, L.F., 2009. Detection of Hammondia heydorni and related coccidia (Neospora caninum and Toxoplasma gondii) in goats slaughtered in Bahia, Brazil. Vet. Parasitol. 162, 156-159.

Slapeta, J.R., Koudela, B., Votypka, J., Modry, D., Horejs, R., Lukes, J., 2002. Coprodiagnosis of Hammondia heydorni in dogs by PCR based amplification of ITS 1 rRNA: differentiation from morphologically indistinguishable oocysts of Neospora caninum. Vet. J. 163, 147-154.

Soares, R.M., Cortez, L.R., Gennari, S.M., Sercundes, M.K., Keid, L.B., Pena, H.F., 2009. Crab-eating fox (Cerdocyon thous), a South American canid, as a definitive host for Hammondia heydorni. Vet. Parasitol. 162, 46-50.

Sreekumar, C., Hill, D.E., Fournet, V.M., Rosenthal, B.M., Lindsay, D.S., Dubey, J.P., 2003. Detection of Hammondia heydorni-like organisms and their differentiation from Neospora caninum using randomamplified polymorphic DNA-polymerase chain reaction. J. Parasitol. 89, 1082-1085.

Wenz, J.R., Moore, D.A., Kasimanickam, R., 2011. Factors associated with the rectal temperature of Holstein dairy cows during the first 10 days in milk. J. Dairy Sci. 94, 1864-1872.

Yalcin, S., Cabuk, M., Bruggeman, V., Babacanoglu, E., Buyse, J., Decuypere, E., Siegel, P.B., 2008. Acclimation to heat during incubation: 3 . Body weight, cloacal temperatures, and blood acid-base balance in broilers exposed to daily high temperatures. Poult. Sci. 87, 2671-2677.

Yamage, M., Flechtner, O., Gottstein, B., 1996. Neospora caninum: specific oligonucleotide primers for the detection of brain "cyst" DNA of experimentally infected nude mice by the polymerase chain reaction (PCR). J. Parasitol. 82, 272-279. 